\title{
The effects of amiodarone on thyroid function
}

\author{
N. S. V. JAGGARAO \\ B.Sc., M.R.C.P. \\ E. N. GRUNDY \\ Ph.D.
}

\author{
JOANNA SHELDON \\ M.D., F.R.C.P. \\ R. VINCENT \\ B.Sc., M.R.C.P.
}

\author{
D. A. Chamberlain \\ M.D., F.R.C.P.
}

Departments of Cardiology, Medicine and Biochemistry, Royal Sussex County Hospital, Brighton BN2 5BE

\section{Summary}

The effects of amiodarone on thyroid function tests in 100 patients treated for 6 weeks to 8 years are reported. One patient became thyrotoxic and 10 developed latent or overt hypothyroidism. Twentyfive patients remained clinically euthyroid throughout, but had free thyroxine indices above the normal range. In these patients with apparently anomalous results, total tri-iodothyronine was normal in 19 cases and low in 1; conversely, free thyroxine was high in all 17 cases in which it was measured. Thyrotrophin releasing hormone (TRH) tests were abnormal in 4 of the 13 patients who had the test. Reverse triiodothyronine was significantly raised after 2 weeks amiodarone in 5 healthy subjects, but an equivalent amount of iodine in 9 healthy individuals did not significantly affect any of these tests. We believe that these changes are due in part to inhibition of peripheral conversion of thyroxine to tri-iodothyropine with diversion to reversed tri-iodothyronine.

Thyroid function tests should be checked once or twice a year in all patients on maintenance amiodarone. Tests indicating hypothyroidism are likely to be clinically relevant, whereas levels of thyroxine suggesting thyrotoxicosis may be misleading and do not usually imply the need to discontinue treatment with the drug.

\section{Introduction}

Amiodarone has been used widely in Europe as an antianginal and antiarrhythmic drug for more than 15 years (Vastesaeger, Gillot and Rasson, 1967). Though available on a named-patient basis in Britain from 1973 (Chamberlain and Clark, 1977), it was licensed for limited clinical use only in early 1981 . Acute toxicity does not occur readily with oral amiodarone and the drug is considered relatively safe. Unwanted effects during maintenance therapy include photosensitivity (Rosenbaum et al., 1976), minor ocular effects (François, 1969), and disorders of thyroid function (Massin et al., 1971).

We have noticed frequent discordance between the results of thyroid function tests and clinical status in our patients treated with amiodarone: we report our experience of the relationship gained over 8 years of observations and advance hypotheses which may account for apparently anomalous results.

\section{Patients and methods}

Serial thyroid function tests were performed on 100 patients treated with amiodarone for 6 weeks to 8 years. Their ages ranged from 33 to 92 years (mean 66 years). All were judged clinically euthyroid when amiodarone was started.

Amiodarone was administered in doses of $600 \mathrm{mg}$ daily for 1 week, $400 \mathrm{mg}$ daily for 1 week, and $200 \mathrm{mg}$ daily subsequently. Once we appreciated how frequently the drug could affect thyroid hormone metabolism we measured thyroid function tests before treatment started and at least 6-monthly thereafter. A total of 53 patients had both baseline and follow-up tests. Most of our earlier patients who had been on treatment for up to 8 years were recalled for the purposes of this study, and 41 of them had only a single test at that time. The remaining 6 patients had serial tests which started after therapy had been commenced.

The free thyroxine index (FTI) was used as the routine screening test in all 100 patients, being derived from the total serum thyroxine (Ratcliffe $e t$ al., 1974) and residual thyroid hormone binding capacity of the serum measured by 'Thyopac 3' 
(Amersham International). Additional thyroid function tests, performed in all patients with abnormal screening tests, included the serum free thyroxine $\left(\mathrm{FT}_{4}\right)$ (Grundy, 1979), the total serum tri-iodothyronine using the Amerlex $T_{3}$ radioimmunoassay kit (Amersham International), the serum thyroid binding globulin (TBG) (Grundy, 1979), and the thyrotrophin releasing hormone (TRH) test using $200 \mu \mathrm{g}$ TRH with measurements of thyrotrophin (TSH) by radioimmunoassay (RIANEN TSH radioimmunoassay Kit, New England Nuclear).

In 5 healthy volunteers all these thyroid function tests together with measurement of serum reverse triiodothyronine (rT3) by radioimmunoassay (Mathur et al., 1979) were performed before and after 2 weeks treatment with $600 \mathrm{mg}$ amiodarone daily.

In another 9 healthy subjects thyroid function was investigated similarly before and after treatment with $18 \mathrm{mg}$ iodine daily, as diluted Lugol's iodine. This amount of iodine is equivalent to that released from $600 \mathrm{mg}$ amiodarone (Broekhuysen, Laruel and Sion, 1969).

Statistical analyses were carried out using Student's $t$-test.

\section{Results}

Fifty-three of the 100 patients had FTI measurements both before and during treatment with amiodarone. In 38 patients the FTI rose and in 15 it fell on treatment, but overall there was a significant rise from a mean of $101 \pm 20$ (s.d.) before amiodarone to a mean of $123 \pm 45$ on amiodarone $(P<0.01)$. Both these mean values were within the normal range.

During treatment the FTI rose above normal in 26 of the 100 patients, remained within the normal range in 70, and fell below normal in 4.

\section{Patients with high FTI}

Twenty-five of the 26 patients whose FTI was raised above normal on amiodarone remained clinically euthyroid throughout. This anomalous result was discovered at intervals ranging from 2 weeks to 4 years after starting treatment. Thyroid binding globulin was not abnormal in any of these patients. In 16 of these 25 patients the free thyroxine concentration was also measured and was raised in all of them (mean 33.7 pmol/litre \pm 8 (s.d.) compared with normal range of 1-26 pmol/litre). By contrast the serum total tri-iodothyronine, measured in 20 of the 25 clinically euthyroid patients with raised FTI, was normal in every case except one in whom it was low (mean $1.8 \mathrm{nmol} /$ litre \pm 0.5 (s.d.) compared with normal range of 1.2-3.4 nmol/litre). Thirteen of these patients had had pre-amiodarone tri-iodothyronine measurements; in these there was a slight but insignificant fall during treatment with amiodarone, from a mean of $2 \cdot 13 \mathrm{nmol} /$ litre before treatment to $1.79 \mathrm{nmol} /$ litre.

TRH tests were performed in 13 of the 25 clinically euthyroid patients with raised FTI and free thyroxine concentrations but with normal tri-iodothyronine levels. The TSH response to TRH was normal in 9 patients, impaired in 2, absent in one, and exaggerated in one.

One patient became clinically thyrotoxic after 20 months treatment. This patient, who had a small nodule in the thyroid, developed heat intolerance and lost $6.5 \mathrm{~kg}$ during the year before thyrotoxicosis was diagnosed. Her total serum thyroxine was $285 \mathrm{nmol} /$ litre (normal 50-145), FTI 349 (normal 50-145) and she showed no rise of TSH in response to TRH. Nevertheless, her serum tri-iodothyronine remained normal at $2.6 \mathrm{nmol} /$ litre (normal 1.2-3.4). Amiodarone was discontinued in this patient and in one other with a raised FTI for reasons unconnected with thyroid function. In both patients the FTI returned to normal after withdrawing the drug, and in the thyrotoxic patient a normal response to TRH was restored without the use of anti-thyroid therapy.

\section{Patients with low FTI}

Four patients became clinically hypothyroid between 24 and 79 months after starting treatment with amiodarone. All had a subnormal FTI and high basal TSH and were treated with thyroxine. Six other patients developed evidence of early hypothyroidism with an FTI at the lower end of the normal range, but with raised basal TSH. The mean pre-treatment FTI in this group of 10 patients $(79 \pm 12$ s.d.) was significantly lower than the mean pre-treatment FTI in the patients as a whole $(102 \pm 20)(P<0.001)$.

\section{Healthy subjects}

The results from 5 healthy subjects given $600 \mathrm{mg}$ amiodarone daily for 2 weeks are shown in Table 1 . In this group there was no significant change in FTI, free thyroxine, or tri-iodothyronine, but there was a significant rise in rT3 from a mean of 0.59 to 1.47 nmol/litre $(P<0.001)$.

Nine normal subjects treated for 2 weeks with iodine equivalent to that released from $600 \mathrm{mg}$ amiodarone showed no significant change in FTI, free thyroxine, tri-iodothyronine, or $\mathrm{rT} 3$, indicating that the rise in rT3 on amiodarone was not due simply to its iodine content.

\section{Discussion}

Amiodarone which contains $75 \mathrm{mg}$ iodine per 200 mg of active substance, bears a structural similarity to thyroxine (Fig. 1). It might affect thyroid function for two reasons: firstly because of its iodine content, and 
TABLE 1. Change in thyroid function in 5 healthy subjects treated for 2 weeks with $600 \mathrm{mg}$ amiodarone daily

\begin{tabular}{|c|c|c|c|}
\hline & Before amiodarone ( \pm s.d.) & After amiodarone ( \pm s.d.) & Significance \\
\hline $\begin{array}{l}\text { Mean FTI } \\
(50-145)\end{array}$ & $100 \pm 5$ & $112 \pm 13$ & NS \\
\hline $\begin{array}{l}\text { Mean FT4 } \\
\text { (10-26 pmol/litre) }\end{array}$ & $17 \cdot 7 \pm 1 \cdot 1$ & $19 \cdot 8 \pm 3 \cdot 0$ & NS \\
\hline $\begin{array}{l}\text { Mean T3 } \\
(1 \cdot 2-3 \cdot 4 \mathrm{nmol} / \text { litre })\end{array}$ & $2 \cdot 36 \pm 0.3$ & $2 \cdot 12 \pm 0 \cdot 3$ & NS \\
\hline $\begin{array}{l}\text { Mean rT3 } \\
(0.29-0.69 \mathrm{mmol} / \text { litre })\end{array}$ & $0 \cdot 59 \pm 0 \cdot 19$ & $1.47 \pm 0.38$ & $P<0.001$ \\
\hline
\end{tabular}

NS $=$ Not significant

Normal values are shown in parentheses.

secondly because of its effect on peripheral thyroid hormone metabolism. Both hypothyroidism and hyperthyroidism have been described in patients on amiodarone (Massin et al., 1971).
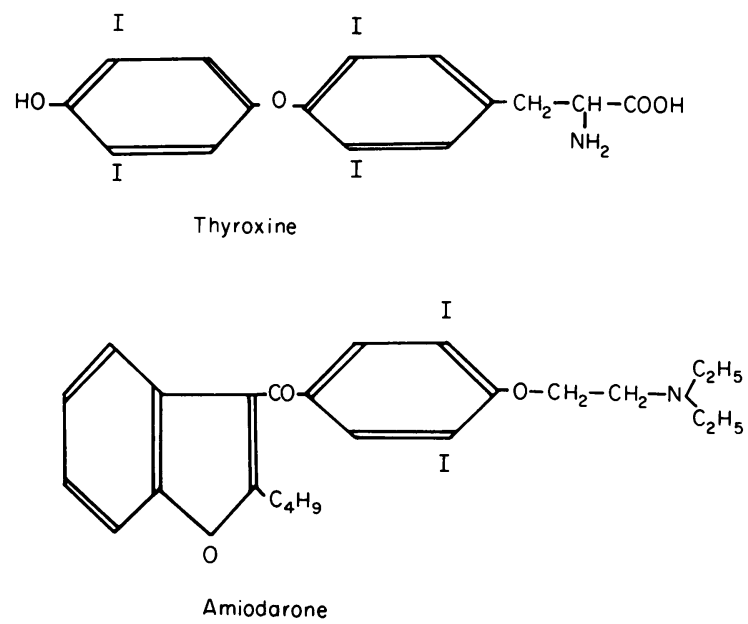

FIG. 1. The chemical structures of thyroxine and amiodarone.

The iodine released from usual therapeutic doses of amiodarone would not, however, be likely to reduce appreciably thyroid hormone release in normal glands, though it could certainly do so in patients with Graves' disease (Wolff, 1969). The observations in our healthy subjects treated with iodine equivalent to that released from amiodarone confirmed this: no significant effect was demonstrable on thyroid function. Similarly, though iodine may provoke hyperthyroidism where there is pre-existing iodine deficiency it very rarely does so in normal glands (Savoie $e t$ al., 1975).

Amiodarone can also influence thyroid hormone metabolism by inhibiting the peripheral conversion of thyroxine to tri-iodothyronine, and enhancing its alternative pathway to reverse tri-iodothyronine, which is metabolically inactive (Burger et al., 1976).
Ten of our 100 patients on long-term amiodarone developed latent or overt hypothyroidism, and one developed hyperthyroidism. Our experience suggests that the development of hypothyroidism during amiodarone therapy is more likely to occur if there is some predisposition to it: the mean pre-amiodarone FTI, while within the normal range, was significantly lower in our patients who developed hypothyroidism than in the series as a whole.

The diagnosis of hyperthyroidism may present considerable difficulty in patients on amiodarone for two reasons. Firstly, the major clinical manifestation of the disease in the elderly may be cardiac, which will be modified by amiodarone; secondly, circulating thyroxine may be raised without clinical manifestations of thyrotoxicosis. Weight loss and heat intolerance were helpful features in our single thyrotoxic patient, whose FTI was also the highest recorded in our patients. The simultaneously normal tri-iodothyronine in this patient was unexpected, but her flat TSH response suggests that her intrapituitary tri-iodothyronine level was high. Perhaps intracellular tri-iodothyronine elsewhere was also high, producing her clinical hyperthyroidism. That the thyrotoxicosis in this patient was induced by amiodarone is inferred from its disappearance on withdrawal of the drug without the need for other therapy.

The striking feature in $25 \%$ of our patients was the raised FTI, though they remained euthyroid due to their normal tri-iodothyronine levels. This can be explained by amiodarone-induced inhibition of the conversion of thyroxine to tri-iodothyronine, with diversion of thyroxine to rT3. This was first postulated by Burger et al. in 1976, and has been described with other drugs including dexamethasone (Chopra et al., 1975), propranolol (Verhoeven et al., 1977), and radiographic contrast media such as iopanoic acid (Bürgi et al., 1976). This does not, however, explain the raised thyroxine levels in our patients on amiodarone, and in the 12 patients described by Pritchard et al. (1975). Raised thyroxine levels could be due to inhibition of hepatic uptake of thyroxine as has been observed with radiographic contrast agents 
(Felicetta, Green and Nelp, 1980). Alternatively, raised thyroxine levels may be due to enzyme inhibition by amiodarone, since the same enzyme is required both for in vitro conversion of thyroxine to tri-iodothyronine and for the completion of the alternative pathway from rT3 to one of its metabolites, di-iodothyronine (Kaplan and Utiger, 1978).

The TRH tests were usually normal in our patients in spite of raised thyroxine levels, consistent with their normal tri-iodothyronine concentrations. But both exaggerated and flat responses to TRH were seen in clinically euthyroid patients with normal triiodothyronine and raised thyroxine levels. These anomalous responses suggest that intrapituitary levels of tri-iodothyronine are not necessarily reflected by circulating levels. The pituitary derives relatively more tri-iodothyronine from thyroxine than do other tissues (Silva and Larsen, 1978). Hence a high thyroxine level might provide the pituitary with sufficient tri-iodothyronine to suppress TSH release, yet insufficient in other tissues to induce clinical hyperthyroidism. Variable results of TRH tests in patients on amiodarone may thus be due both to a variable increase in circulating thyroxine and to a variable degree of inhibition of thyroxine to triodothyronine conversion both within the pituitary and peripherally.

In conclusion, although both hypothyroidism and hyperthyroidism may be induced by amiodarone, these are relatively rare complications. A high circulating thyroxine is not, however, uncommon in patients on amiodarone, though such patients usually remain clinically euthyroid with normal tri-iodothyronine levels. In these circumstances the drug need not be withdrawn, but regular observation is essential. In doubtful cases, especially having regard to the influence of excess thyroid activity on cardiac arrhythmias, amiodarone should be discontinued. TRH tests are usually helpful but the serum triiodothyronine is probably the most helpful standard thyroid function test in this situation.

\section{Acknowledgments}

We thank Dr P. Marsden and Mr H. Keighley at Greenwich District General Hospital for measurements of reverse T3. Dr Jaggarao was in receipt of a British Heart Foundation Overseas Visiting Fellowship.

\section{References}

BROEKHUYSEN, J., LARUEL, R. \& SION, R. (1969) Recherches dans la serie des benzofurannes. XXXVII. Etude comparée du transit et du métabolisme de l'amiodarone chez diverses especes animales et chez l'homme. Archives Internationales de Pharmacodynamie et de Therapie, 177, 340.
Burger, A., Dinichert, D., Nicod, P., JenNey, M., LemarChandBERAUD, T. \& VALLOTTON, M.B. (1976) Effect of amiodarone on serum triiodothyronine, reverse triiodothyronine, thyroxin and thyrotropin. A drug influencing peripheral metabolism of thyroid hormones. Journal of Clinical Investigation, 58, 255.

BÜRi, H., WimpFHeIMER, C., BURger, A., Zaunbauer, W., RosLER, H. \& LEMARCHAND-BERAUD, T. (1976) Changes of circulating thyroxine, triiodothyronine and reverse triiodothyronine after radiographic contrast agents. Journal of Clinical Endocrinology and Metabolism, 43, 1203.

Chamberlain, D.A. \& ClarK, A.N.G. (1977) Atrial fibrillation complicating Wolff-Parkinson-White syndrome treated with amiodarone. British Medical Journal, 2, 1519.

Chopra, I.J., Williams, D.E., ORgiazzi, J. \& Solomon, D.H. (1975) Opposite effects of dexamethasone on serum concentrations of $3,3^{\prime}, 5^{\prime}$-triiodothyronine (reverse $T_{3}$ ) and $3,3^{\prime}, 5$ triiodothyronine $\left(\mathrm{T}_{3}\right)$. Journal of Clinical Endocrinology and Metabolism, 41, 911.

FelicetTA, J.V., GReEN, W.L. \& NelP, W.B. (1980) Inhibition of hepatic binding of thyroxine by cholecystographic agents. Journal of Clinical Investigation, 65, 1032.

FRANÇOIS, J. (1969) Cornea verticillata. Documenta Ophthalmologica, 27, 235.

GRUNDY, E.N. (1979) Assessment of thyroid function. D. Phil. thesis. University of Sussex, 260-69.

KAPLAN, M.M. \& UTIGER, R.D. (1978) Iodothyronine metabolism in rat liver homogenates. Journal of Clinical Investigation, 61, 459.

Massin, J.P., Thomopoulos, P., KaraM, J. \& SAvole, J.C. (1971) Le risque thyroidien d'un nouveau coronadilateur iode. L'Amiodarone (Cordarone). Annales d'endocrinologie (Paris), 32, 437.

MathUR, H., Ekins, R.P., Brown, B.L. Malan, P.G. \& KuRTz, A.B. (1979) Correction for the presence of cross reactants in saturation assays. Application to thyroxine cross reactivity in reverse $T_{3}$ radioimmunoassay. Clinica chimica Acta, 91, 317.

Pritchard, D.A., Singh, B.N. \& HURLey, P.J. (1975) Effects of amiodarone on thyroid function in patients with ischaemic heart disease. British Heart Journal, 37, 856.

Ratcliffe, W.A., RATCliffe, J.G., MCBride, A.D., HaRland, W.A. \& RANDALL, T.W. (1974) The radioimmunoassay of thyroxine in unextracted human serum. Clinical Endocrinology, 3 , 481.

Rosenbaum, M.B., Chiale, P.A., Halpern, M.S., NaU, G.J., PRZYbYlSKi, J., LeVI, R.J., LAZZARI, J. \& ElizarI, M.V. (1976) Clinical efficacy of amiodarone as an antiarrhythmic agent. American Journal of Cardiology, 38, 934.

Savoie, J.C., Massin, J.P., Thomopoulos, P. \& Leger, F. (1975) Iodine induced thyrotoxicosis in apparently normal thyroid glands. Journal of Clinical Endocrinology and Metabolism, 4, 685 .

SILVA, J.E. \& LARSEN, P.R. (1978) Contributions of plasma triiodothyronine and local thyroxine monodeiodination to triiodothyronine to nuclear triiodothyronine receptor saturation in pituitary, liver, and kidney of hypothyroid rats. Further evidence relating saturation of pituitary nuclear triiodothyronine receptors and the acute inhibition of thyroid stimulating hormone release. Journal of Clinical Investigation, 61, 1247.

VAstesaeger, M., Gillot, P. \& RAsson, G. (1967) Etude clinique d'une nouvelle médication anti-angoreuse. Acta cardiologica (Bruxelles), 22, 483.

Verhoeven, R.P., Visser, T.J., Doctor, R., Henneman, G. \& SCHAleKaMP, M.A. (1977) Plasma thyroxine 3, 3', 5-triiodothyronine and 3, 3', 5'-triiodothyronine during beta-adrenergic blockade in hyperthyroidism. Journal of Clinical Endocrinology and Metabolism, 44, 1002.

WOLFF, J. (1969) Iodide goitre and the pharmacologic effects of excess iodine. American Journal of Medicine, 47, 101. 